\title{
Climatological analysis of passage-type tropical cyclones from the Western North Pacific into the South China Sea
}

\author{
Jau-Ming Chen ${ }^{1, *}$, Pei-Hua Tan ${ }^{2}$, Liang Wu ${ }^{3}$, Jin-Shuen Liu ${ }^{1}$, and Hui-Shan Chen ${ }^{1}$ \\ ${ }^{1}$ Department of Maritime Information and Technology, National Kaohsiung Marine University, Kaohsiung City, Taiwan \\ ${ }^{2}$ Department of Applied History, National Chiayi University, Chiayi City, Taiwan \\ ${ }^{3}$ Center for Monsoon System Research, Institute of Atmospheric Physics, Chinese Academy of Sciences, Beijing, China
}

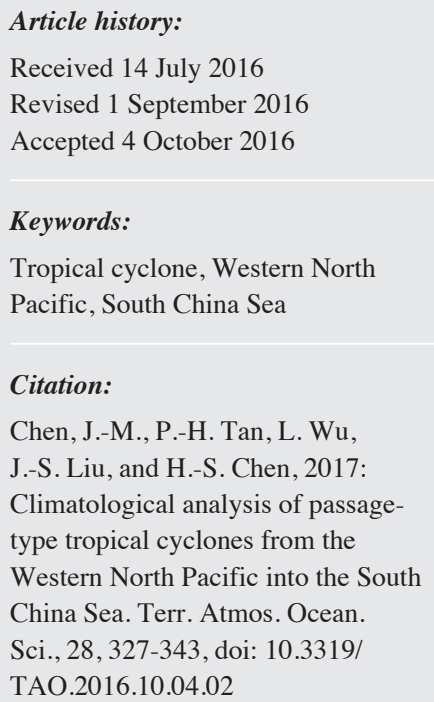

Received 14 July 2016

Revised 1 September 2016

Accepted 4 October 2016

Keywords:

Tropical cyclone, Western North

Pacific, South China Sea

Citation:

Chen, J.-M., P.-H. Tan, L. Wu, J.-S. Liu, and H.-S. Chen, 2017: Climatological analysis of passagetype tropical cyclones from the Western North Pacific into the South China Sea. Terr. Atmos. Ocean. Sci., 28, 327-343, doi: 10.3319/ TAO.2016.10.04.02

\begin{abstract}
Tropical cyclone (TC) climatological characteristics with passage from the Western North Pacific (WNP) into the South China Sea (SCS) during the June - November season are analyzed in this study. These TCs tend to form in the WNP west of $150^{\circ} \mathrm{E}$, and on average westward by $7-12^{\circ}$ in longitude than TCs that do not track into the SCS. Their formation locations migrate with the monsoon trough, moving northward from June to August, and southward from September to November. The probability of a WNP TC moving into the SCS varies seasonally, with only $12-18 \%$ of the WNP TCs doing so during August-September due to more northern TC formation. However, this probability rises to $25-26 \%$ in June - July and $25-32 \%$ in October - November with more southern TC formation. The passage-type TCs generally form in the eastern part of an elongated lower-level cyclonic anomaly of the 10-day low-pass filtered environmental circulation in the $10-20^{\circ} \mathrm{N}$ zone, which is paired with an anticyclonic anomaly to the north. Between this circulation pair, anomalous easterly flows steer these TCs westward, giving them a westward track into the SCS. The formation of these passage-type TCs is associated with a southward displacement of the monsoon trough and a westward intensification of the Pacific subtropical high in August and September. During June - July (October - November), the associated features appear as a southeastward (meridional) expansion of the monsoon trough and a northward displacement of the Pacific subtropical high.
\end{abstract}

\section{INTRODUCTION}

The South China Sea (SCS) is a marginal sea to the west of the Western North Pacific (WNP). The WNP and SCS cover large tropical domains and thus feature significant tropical cyclone (TC) activity. Worldwide, TC activity is most intense over the WNP. TC formation is largely related to monsoon trough-related circulation features, including confluence zones, shear lines, and monsoon gyres (e.g., Ritchie and Holland 1999; Chen et al. 2004; Yoshida and Ishikawa 2013). On average, the annual TC formation count in the WNP is about 25.7 (e.g., Neumann 1993). After formation, the WNP TCs generally move westward/northwestward toward the SCS/East Asia or northward toward Japan/ the Northern North Pacific (e.g., Harr and Elsberry 1991; Lander 1996; Wu and Wang 2000; Elsner and Liu 2003).

\footnotetext{
* Corresponding author

E-mail: cjming@mail.nkmu.edu.tw
}

The WNP TC tracks are divided into seven track types (e.g., Camargo et al. 2007). Based upon TC track fuzzy clustering, Chu et al. (2010) and Kim et al. (2012) demonstrated seven major TC tracks in the WNP-SCS regions, composed of four northward-recurving tracks and three straight-moving tracks. The northward movements are mainly along these zones: $125-140^{\circ} \mathrm{E}, 130-150^{\circ} \mathrm{E}, 140-155^{\circ} \mathrm{E}$, and $155-165^{\circ} \mathrm{E}$ (see Fig. 1 of Chu et al. 2010). The straight movements include a northwestward track from the Philippine Sea/WNP toward Taiwan/southeast China, a westward track from the WNP through the SCS into Vietnam/South China, and a westward track for TCs with formation and subsequent movement within the SCS. In accordance with these tracks, TC activity can effectively modulate rainfall variability in Taiwan, southeast China and Hong Kong on various timescales (e.g., Chen and Chen 2011; Chen et al. 2013; Li and Zhou 2015; Li et al. 2015). On average, about 
10.3 TCs appear in the SCS annually (e.g., Wang et al. 2007). The above analyses portray TC activity in the SCS as having two major components: in situ formation within the SCS and passage from the WNP into the SCS (e.g., Ling et al. 2011).

Wang et al. (2007) showed that TC formation in the SCS mainly occurs in the northern basin during the southwest monsoon season (May - September), while shifting to the southern basin during the northeast monsoon season (October - December). During the southwest monsoon season, warm waters and high humidity provide favorable conditions for TC genesis throughout the entire SCS domain. The presence of a monsoon trough over the northern basin is accompanied with strong positive vorticity and weak vertical wind shear, which facilitate the formation of most TCs in this region. During the northeast monsoon season, the monsoon trough displaces southward to enhance the development of deep cumulus convection over the central and southern basins. All environmental factors, including sea surface temperature, relative humidity, vorticity, and vertical wind shear, are only favorable for TC formation in the southern basin. Lee et al. (2006) showed that increased vertical wind shear tends to prohibit TC formation in the SCS during the May - June season. During the November - December season weakening northeasterly flows act to weaken vertical wind shear giving rise to greater TC formation in the SCS (Lin and Lee 2011). TC formation in the SCS exhibits evident interannual and interdecadal variations (e.g., Wang et al. 2012, 2014; Yan et al. 2012; Zhao et al. 2014).

In addition to in situ formation, a large portion of TC activity in the SCS is caused by the passage of TCs from the WNP into the SCS. In the WNP, the location of TC genesis can be modulated by environmental factors such as vertical wind shear, sea surface temperature (SST), and the strength and location of the Pacific subtropical high and monsoon trough (e.g., Chia and Ropelewski 2002; Huang et al. 2011; Tippett et al. 2011; Li and Zhou 2013). The appearance of an anomalous anticyclonic circulation over the WNP causes vertical wind shear enhancement and thus suppresses TC genesis (e.g., Chen et al. 2005). On the other hand, monsoon trough enhancement provides a favorable environment for the formation and growth of TCs (e.g., Ko and Hsu 2006). During the warm years, the eastward displacement of warm waters in the tropical Pacific is accompanied with eastward extensions of the monsoon trough and equatorial westerlies (e.g., Lander 1994a). These extensions result in a shift in TC-genesis location to the southeast relative to typical years (e.g., Wang and Chan 2002; Camargo and Sobel 2005; Chen et al. 2006). The enhancement of equatorial westerlies slows TC movement toward the west and allows more time for Beta drift to guide the storm toward a northward recurving track (e.g., Zhao et al. 2011; Kim et al. 2013; Colbert et al. 2015). Chen (2011) demonstrated that a canonical El Niño induces an anomalous cooling in the
Maritime Continent and an anomalous anticyclone across the SCS-Philippine Sea, leading to suppressed TC activity in the SCS during the fall season. Choi et al. (2010) showed that during a negative Pacific-Japan phase, an anomalous anticyclone centering to the east of Taiwan steers the WNP TCs westward into the SCS via anomalous easterlies over its southern boundary. It appears that the WNP TC tracks are jointly affected by genesis location and large-scale environmental steering flows (e.g., Harr and Elsberry 1995a, b; Wu and Wang 2004). Camargo et al. (2007) demonstrated that $500-\mathrm{hPa}$ steering flows are more zonal in the straightmoving clusters of the WNP TCs, while larger meridional components occur in recurving clusters. The WNP TCs moving with a straight track present a noticeable source of TC activity in the SCS.

Following the above research results, it is of interest to examine the characteristics of two different types of TC activity in the SCS: in situ formation and passage of TCs into the SCS. In this study, the analyzed SCS domain is defined as $108-120^{\circ} \mathrm{E}, 5-22^{\circ} \mathrm{N}$, as shown by the rectangular box in Fig. 1. The characteristics of these two TC features in the SCS domain are portrayed by best track data from the Joint Typhoon Warning Center (JTWC). The TCs analyzed in this paper have tropical storm intensity or greater. The time and location of a TC with maximum sustained wind speeds greater than or equal to 34 knots delineated by track records define the start of its lifetime. Total TC formation and TC passage counts in each calendar month throughout 1950 - 2010 are shown in Fig. 2a. The in situ TC formation (grey bar) reaches a maximum phase in September (54 TCs) and August (43 TCs), reflecting an active period during these two months (e.g., Haghroosta and Ismail 2013). The total formation numbers during $1950-2010$ is 236 . The average annual number of TC formed is 3.86 , comparable to

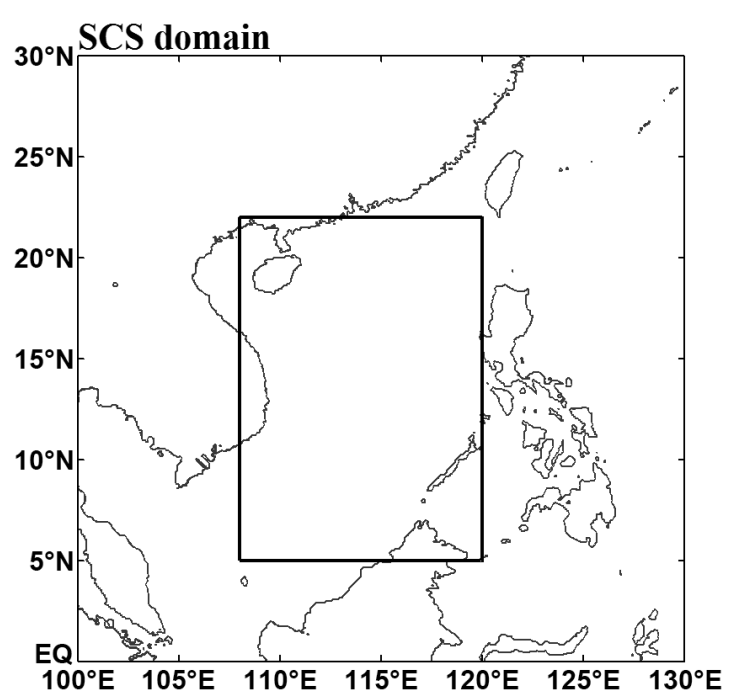

Fig. 1. The South China Sea analysis domain indicated by a rectangular box. 

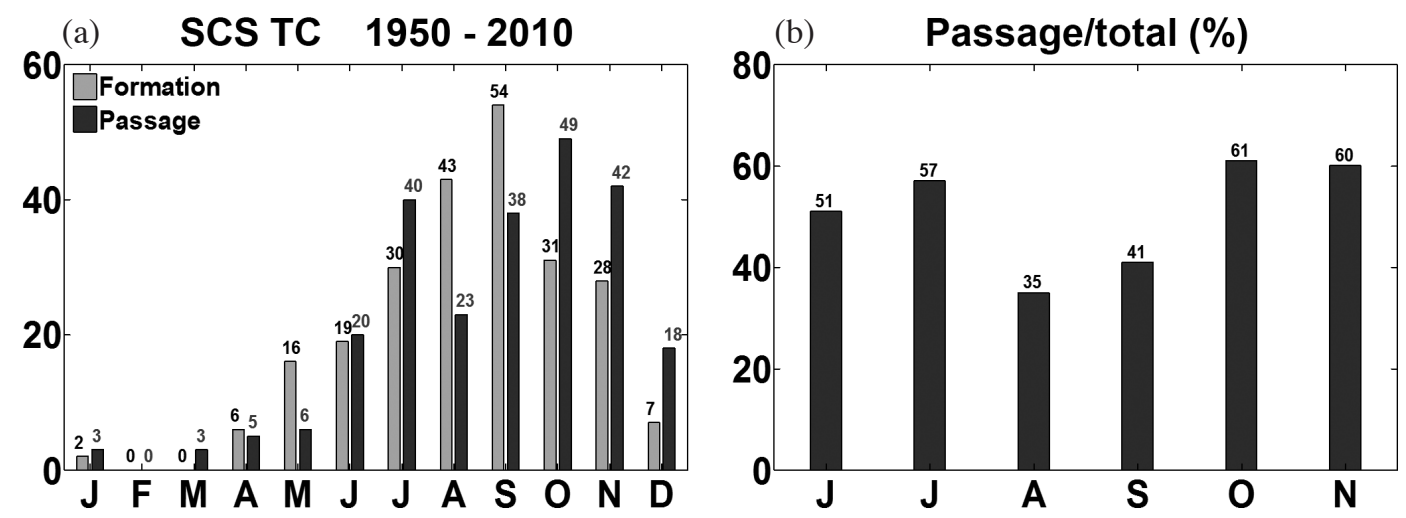

Fig. 2. (a) The TC monthly counts with formation within or passage into the South China Sea. (b) The ratio of passage-type TCs to total TCs in the South China Sea for the months of June to November. Unit: percentage.

the number of 3.9 estimated by Lin and Lee (2011) with an analysis using 1972 - 2005 data.

A TC forming out of the SCS, but later appearing in the SCS is hereafter, referred to as a passage-type TC. The number of TC passage into the SCS (dark bar) reaches a maximum phase in October (49 TCs) and November (42 TCs). The passage number is larger than the formation number in October and November, but vice versa in August and September. Total TC counts (formation plus passage) are high during fall (70 - $92 \mathrm{TCs}$ ) and summer (39 - $73 \mathrm{TCs})$, but very low during spring and winter (smaller than $25 \mathrm{TCs}$ ). The June-November period is considered the major TC season in the SCS and thus analyzed in this study. During the major TC season, numbers of TC formation and TC passage are 205 and 212, respectively. This shows the comparable importance of these two TC features to total TC activity in the SCS. The relative importance of passage-type TCs exhibits clear seasonality. As shown in Fig. 2b, the relative percentages of passage-type TCs to total TCs are greater than $50 \%$ in June and July, less than 50\% in August and September, and more than $60 \%$ in October and November.

Past studies related to TC activity in the SCS focused mainly on TC formation and/or total TC activity (e.g., Ho et al. 2004; Wang et al. 2007; Huang and Guan 2012; Zhao et al.2014). The specific characteristics of TC passage from the WNP into the SCS, so far, have not been comprehensively analyzed. The main purpose of this study is to examine the characteristics of passage-type TCs from the WNP into the SCS during the major TC season from June to November. The main questions raised in this study are as follows:

(1) What are the formation features of passage-type TCs in the WNP during the major TC season? How do seasonal circulations modulate formation features?

(2) How do large-scale environmental circulations facilitate the movement of passage-type TCs from the WNP into the SCS? In particular, what are the corresponding variations in the monsoon trough and the Pacific subtropical high? How do these variation features facilitate TC movement from the WNP toward the SCS?

Answers to the above questions should disclose the primary characteristics needed for monitoring and predicting TC activity in the SCS. The processes regulating TC passage from the WNP into the SCS should provide greater insight into large-scale interaction processes between the WNP and SCS.

\section{DATA}

Two data sets are used in this study to examine TC characteristics and associated large-scale circulation features. The 6-hr data from the JTWC TC best tracks (Chu et al. 2002) are employed to analyze TC activity for the SCS and WNP. The analyzed characteristics include: formation locations, formation numbers, passage frequency, and movement tracks. Seasonal background conditions associated with different types of TC activity are interpreted from large-scale atmospheric fields. The daily National Centers for Environmental Prediction-National Center for Atmospheric Research (NCEP-NCAR) reanalysis data (Kalnay et al. 1996) are used to portray atmospheric processes modulating TC activity. The analysis period spans from 1950 2010 .

\section{FORMATION FEATURES OF PASSAGE-TYPE TCS}

TC activity characteristics are generally examined in terms of three aspects: count, formation location, and track (e.g., Mei et al. 2015). These three aspects of passage-type TCs are examined for the major TC season. In TC count, TCs formed in the WNP $\left(120-180^{\circ} \mathrm{E}, 5-22^{\circ} \mathrm{N}\right)$ are separated into two types: with and without a passage into the SCS. The former are passage-type TCs referred to previously, while the latter are referred to as non-passage-type TCs. Monthly-accumulated TC counts of these two types during $1950-2010$ are shown in Fig. 3a. The WNP TCs with a 
passage into the SCS (dark bar) exhibit the same numbers as those shown in Fig. 2a. This shows that passage-type TCs arriving in the SCS are all originally from the WNP. The numbers of passage-type TCs are significantly smaller than non-passage type. The percentages of passage-type TCs with respect to total WNP TCs are $25-26 \%$ in June - July, decreasing to 12 - $18 \%$ in August - September, and increasing to $25-32 \%$ in October - November (Fig. 3b), revealing clear seasonal variability. The WNP TCs moving into the SCS mainly follow a straight westward track (e.g., Chu et al. 2010; Kim et al. 2012). TC tracks have been found to be closely modulated by factors associated with formation location and large-scale steering flows (e.g., Ho et al. 2004; Zhao et al. 2011). Seasonal characteristics of these factors should also be examined.

The formation locations of all TCs formed in the WNP regions are displayed in Fig. 4. The formation location of a passage-type (non-passage-type) TC is marked with a solid (an empty) circle. It is clear to see that all passage-type TCs during summer (June - August) are formed in regions to the west of $150^{\circ} \mathrm{E}$. The formation locations stretch eastward for passage-type TCs during fall, near $170^{\circ} \mathrm{E}$ in September -
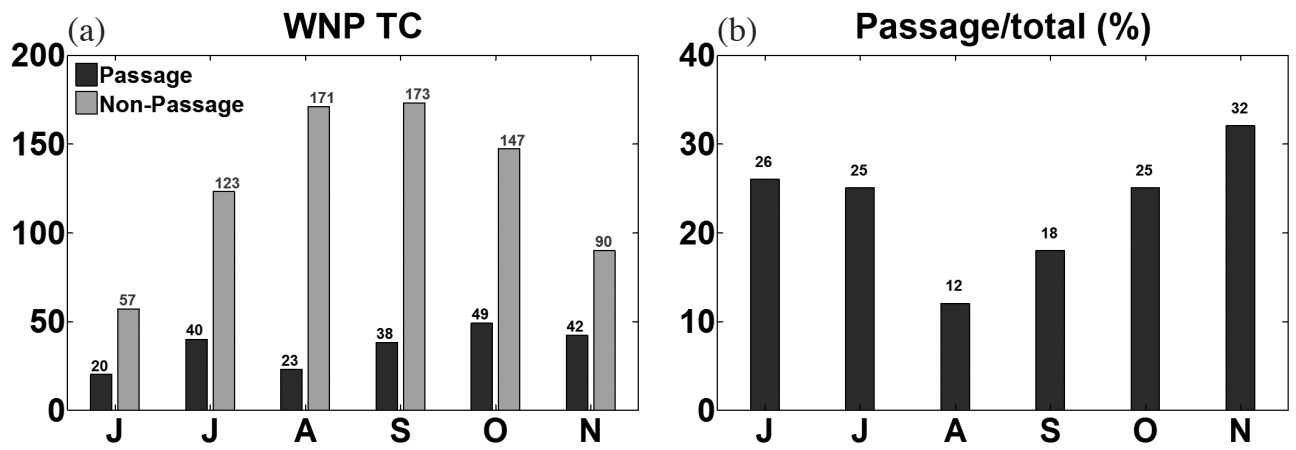

Fig. 3. (a) The WNP TC monthly count with or without passage into the South China Sea. (b) The ratio of passage-type TCs to total TCs in the WNP for the months of June to November. Unit: percentage.
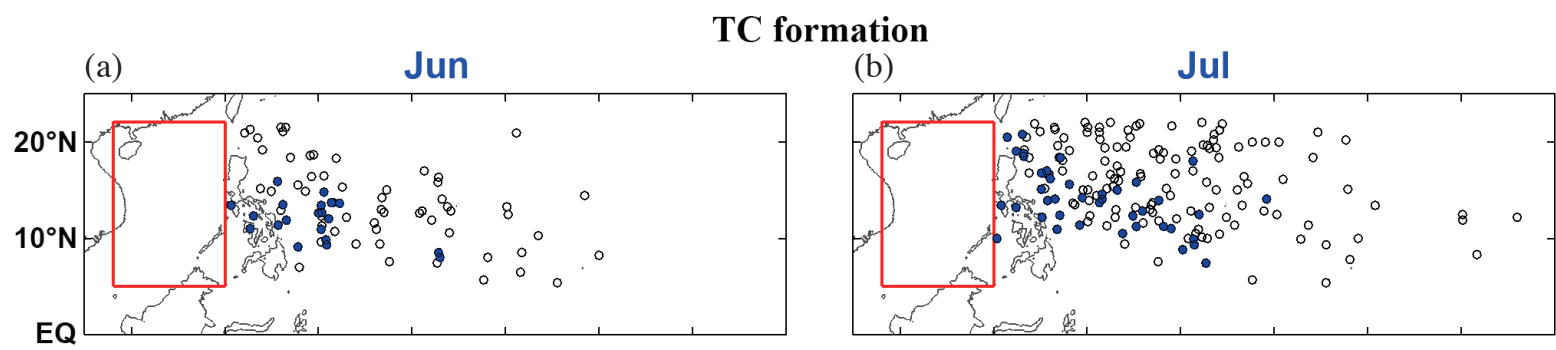

(c)

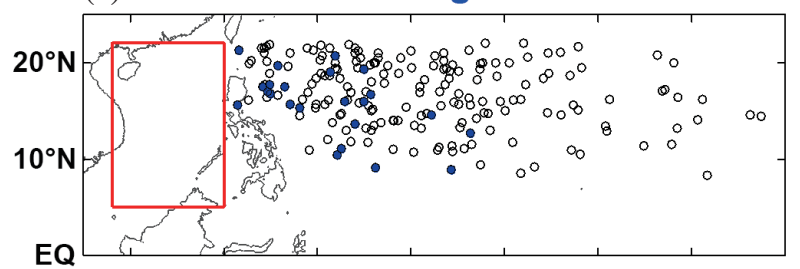

(e)

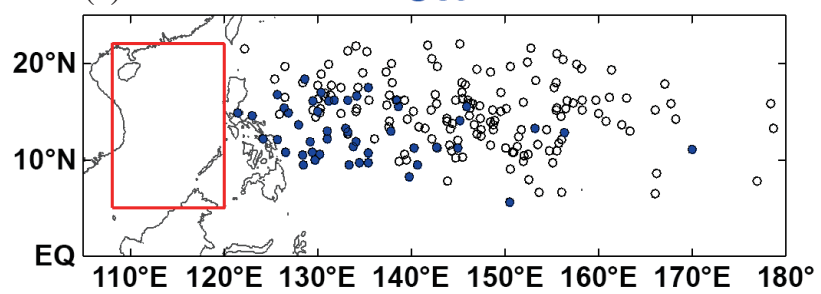

(d)

Sep

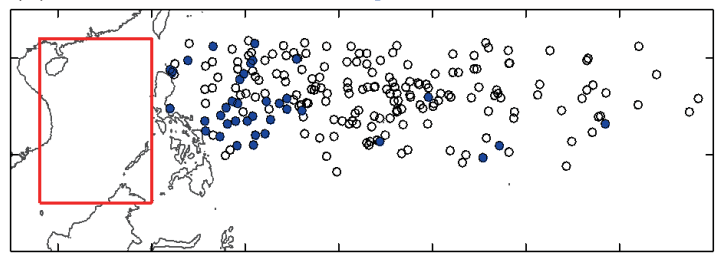

(f)

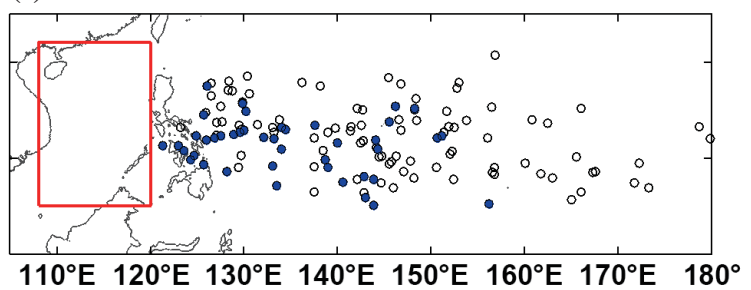

Fig. 4. The formation locations for WNP TCs with passage (solid circle) or without passage (open circle) into the South China Sea for (a) June, (b) July, (c) August, (d) September, (e) October, and (f) November. The rectangular box indicates the South China Sea analysis domain. (Color online only) 
October and $160^{\circ} \mathrm{E}$ in November. Our analyses indicate that $100 \%(92-93 \%)$ of the passage-type TCs are formed to the west of $150^{\circ} \mathrm{E}$ during summer (fall). The above formation patterns exhibit a northwest-southeast distribution. In the eastern part of the WNP, most TCs tend to have a recurving track toward the northern North Pacific due to more time under the influence of Beta drift. In order to have a westward track to reach the SCS, the formation location indicates that the passage-type TCs tend to form at a lower-latitude.

The average formation locations for passage-type and non-passage-type TCs are computed and shown in Fig. 5. Their corresponding positions in longitude and latitude are listed in Table 1. The average passage-type TC formation location (marked with a solid circle) moves northward from June to August, and displaces southward from September to November. TCs tend to form in a more northern region during August and September. Zonally, TCs tend to form in a more eastern region during fall than during summer. For non-passage-type TCs, their average formation location (marked with an asterisk) exhibits a similar meridional seasonal migration as passage-type TCs, except they are forming in a more eastern region. As shown in Table 1, eastward displacement in formation locations from passage type to non-passage type is $7.28-10.83^{\circ}$ during summer, but increases to $11.23-12.37^{\circ}$ during fall. The above comparisons indicate that formation in a more western location acts as a favorable factor in facilitating WNP TC movement into the SCS. This is consistent with the previous finding that the WNP TCs forming in a more eastern region favor a northward-recurving track over a westward track (e.g., Harr and Elsberry 1991; Zhao et al. 2011; Kim et al. 2013). By comparing Figs. 3b and 5, one can find that WNP TC formation in a more northern (southern) region is associated with a lower (higher) percentage of the WNP TCs moving into the SCS. Specifically, the relative percentage of passage-type TCs to total WNP TCs is only 12\% in August and $18 \%$ in September, but increases to $26 \%$ in June and $32 \%$ in November. The above results reveal two salient seasonal features for passage-type TCs: a meridional migration of formation locations and varying probability of moving into the SCS. These two features are likely to be influenced by large-scale seasonal circulations. The corresponding modulating effects are thus investigated.

\section{SEASONAL MODULATIONS OF LARGE-SCALE CIRCULATIONS}

TC formation in the western tropical Pacific is

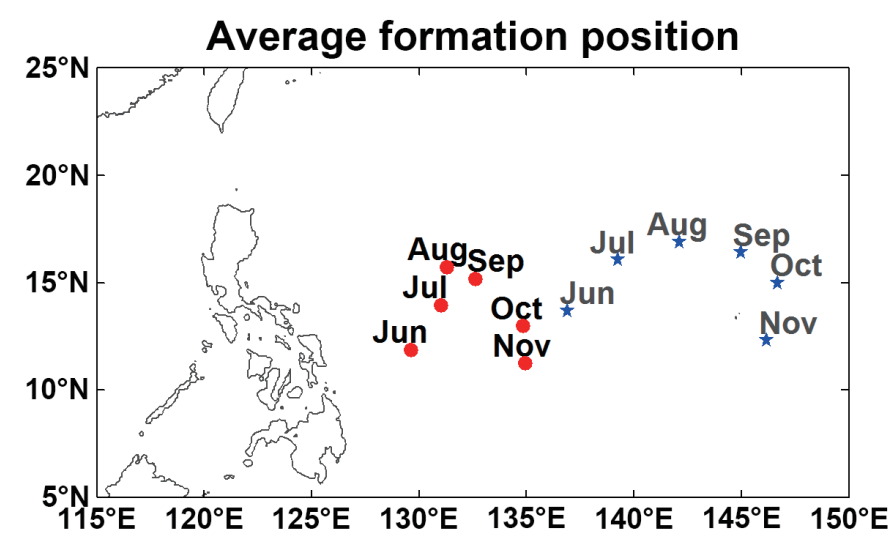

Fig. 5. The average formation locations for WNP TCs with passage (solid circle) or without passage (asterisk) into the South China Sea for the months of June to November. (Color online only)

Table 1. The average formation locations of the WNP TCs for passage and nonpassage types and their difference (non-passage minus passage).

\begin{tabular}{c|cc|c}
\hline WNP TCs & \multicolumn{2}{|c|}{ Average formation location } & \\
\hline month & passage type & non-passage type & difference (lon., lat.) \\
\hline June & $129.62^{\circ} \mathrm{E}, 11.89^{\circ} \mathrm{N}$ & $136.90^{\circ} \mathrm{E}, 13.69^{\circ} \mathrm{N}$ & $\left(7.28^{\circ}, 1.8^{\circ}\right)$ \\
July & $131.02^{\circ} \mathrm{E}, 13.96^{\circ} \mathrm{N}$ & $139.25^{\circ} \mathrm{E}, 16.07^{\circ} \mathrm{N}$ & $\left(8.23^{\circ}, 2.11^{\circ}\right)$ \\
August & $131.27^{\circ} \mathrm{E}, 15.75^{\circ} \mathrm{N}$ & $142.10^{\circ} \mathrm{E}, 16.90^{\circ} \mathrm{N}$ & $\left(10.83^{\circ}, 1.15^{\circ}\right)$ \\
September & $132.59^{\circ} \mathrm{E}, 15.19^{\circ} \mathrm{N}$ & $144.96^{\circ} \mathrm{E}, 16.40^{\circ} \mathrm{N}$ & $\left(12.37^{\circ}, 1.21^{\circ}\right)$ \\
October & $134.81^{\circ} \mathrm{E}, 12.99^{\circ} \mathrm{N}$ & $146.69^{\circ} \mathrm{E}, 14.99^{\circ} \mathrm{N}$ & $\left(11.88^{\circ}, 2.0^{\circ}\right)$ \\
November & $134.93^{\circ} \mathrm{E}, 11.27^{\circ} \mathrm{N}$ & $146.16^{\circ} \mathrm{E}, 12.31^{\circ} \mathrm{N}$ & $\left(11.23^{\circ}, 1.04^{\circ}\right)$ \\
\hline
\end{tabular}


noticeably modulated by the monsoon trough (e.g., McBride 1995), which can be clearly illustrated using lower-tropospheric circulations. Climatological (1950 - 2010)-mean 850 -hPa winds and height are used to depict how largescale circulations modulate meridional migration in formation locations of passage-type TCs. As shown in Fig. 6, the monsoon trough extends southeastward during June - September, but stretches zonally during October - November. It exhibits evident meridional movements throughout summer and fall over the western tropical Pacific. The axis of the monsoon trough over $130^{\circ} \mathrm{E}$ is taken as an example for discussions. It is interpreted from the location at the center of the cyclonic shear circulation that is denoted by an aster- isk in Fig. 6. In summer, the trough axis moves northward from about $6^{\circ} \mathrm{N}$ in June to $13^{\circ} \mathrm{N}$ in July and $17^{\circ} \mathrm{N}$ in August. In fall, the axis moves southward from $16^{\circ} \mathrm{N}$ in September to $11.5^{\circ} \mathrm{N}$ in October and $7.5^{\circ} \mathrm{N}$ in November. Overall, the monsoon trough migrates meridionally, moving northward during summer and southward during fall (e.g., Lander 1994a). In all months, passage-type TCs tend to form within the monsoon trough (denoted by a solid circle). Their formation locations thus follow the monsoon trough, migrating northward during summer and southward during fall. This result is consistent with the analyses of Chen and Weng (1998) where TC formation is effectively modulated by the monsoon trough.
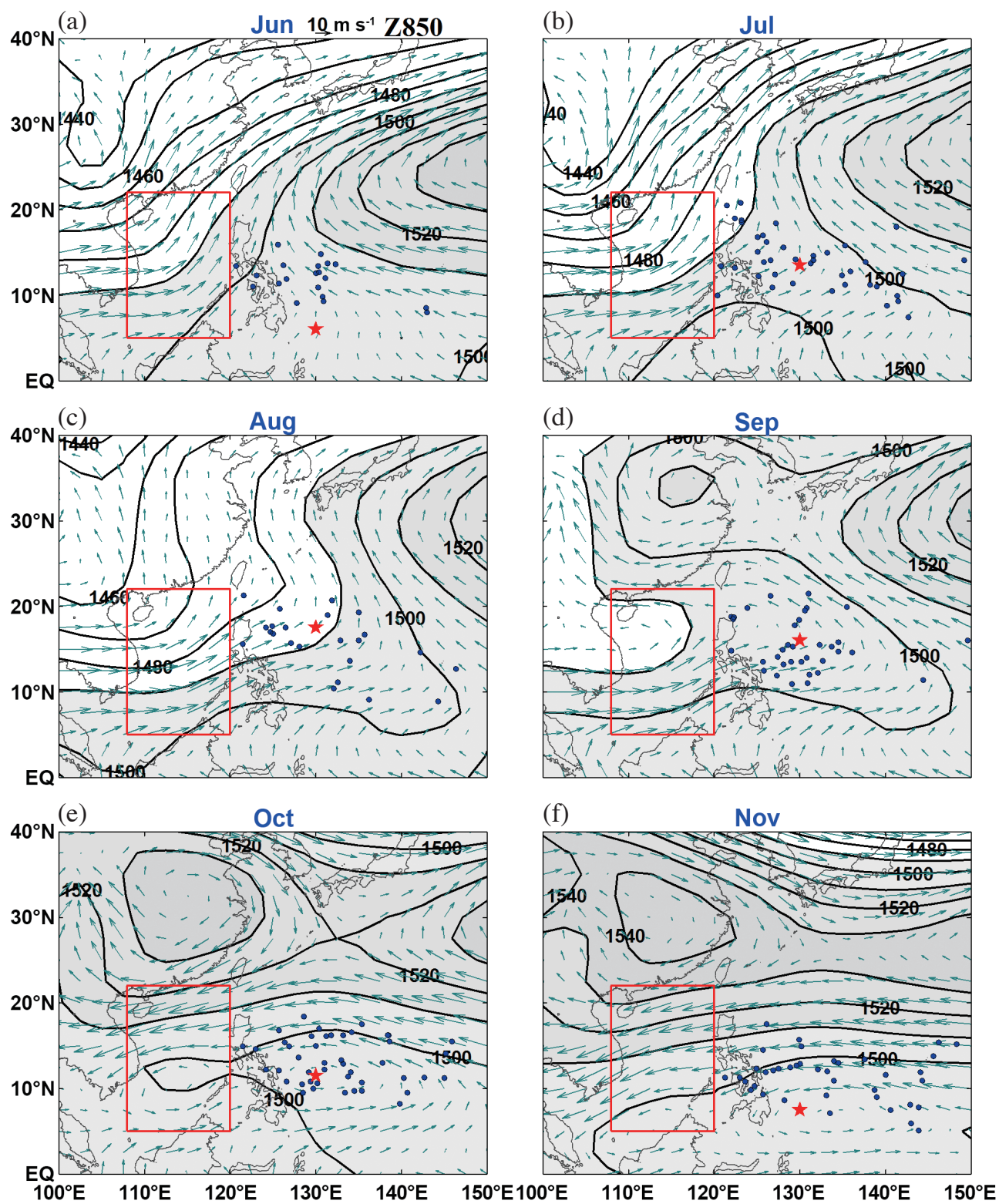

Fig. 6. The monthly climatological means of 850-hPa height and wind fields for (a) June, (b) July, (c) August, (d) September, (e) October, and (f) November. The formation locations of passage-type TCs into the SCS are indicated by the solid circles. The asterisk mark denotes the axis position of the monsoon trough along $130^{\circ} \mathrm{E}$. The analysis domain of the SCS is illustrated by the rectangular box. (Color online only) 
Seasonal variations in probability for a WNP TC to move into the SCS are likely related to changes in major TC tracks among different months. TC tracks are generally considered to be highly controlled by steering flows, which are normally represented by $500-\mathrm{hPa}$ circulations (e.g., Wu and Wang 2004; Camargo et al. 2007; Takahashi and Yasunari 2008). The seasonal features of steering flows are delineated by 1950 - 2010 means of 500-hPa winds and height. TC track features are interpreted from TC frequency represented by total TC appearance counts in every $2^{\circ} \times 2^{\circ}$ box averaged from the $1950-2010$ period using the 6-hr JTWC best track data records. TC frequency analyzed here includes only WNP TC movements. Movements associated with TCs formed in the SCS are excluded specifically to examine the passage features from the WNP into the SCS.

Figure 7 shows patterns of steering flows and TC frequency for June to August. During summer, the Pacific subtropical high at $500 \mathrm{hPa}$ extends westward toward the northern SCS in June, but northwestward toward eastern China and the East China Sea in July and August. The axis of the subtropical high along $120^{\circ} \mathrm{E}$ (denoted by an asterisk) is interpreted from the location at the center of the $500-\mathrm{hPa}$ anticyclonic shear circulation. It is at about $20^{\circ} \mathrm{N}$ in June, $25^{\circ} \mathrm{N}$ in July, and $27.5^{\circ} \mathrm{N}$ in August, showing a
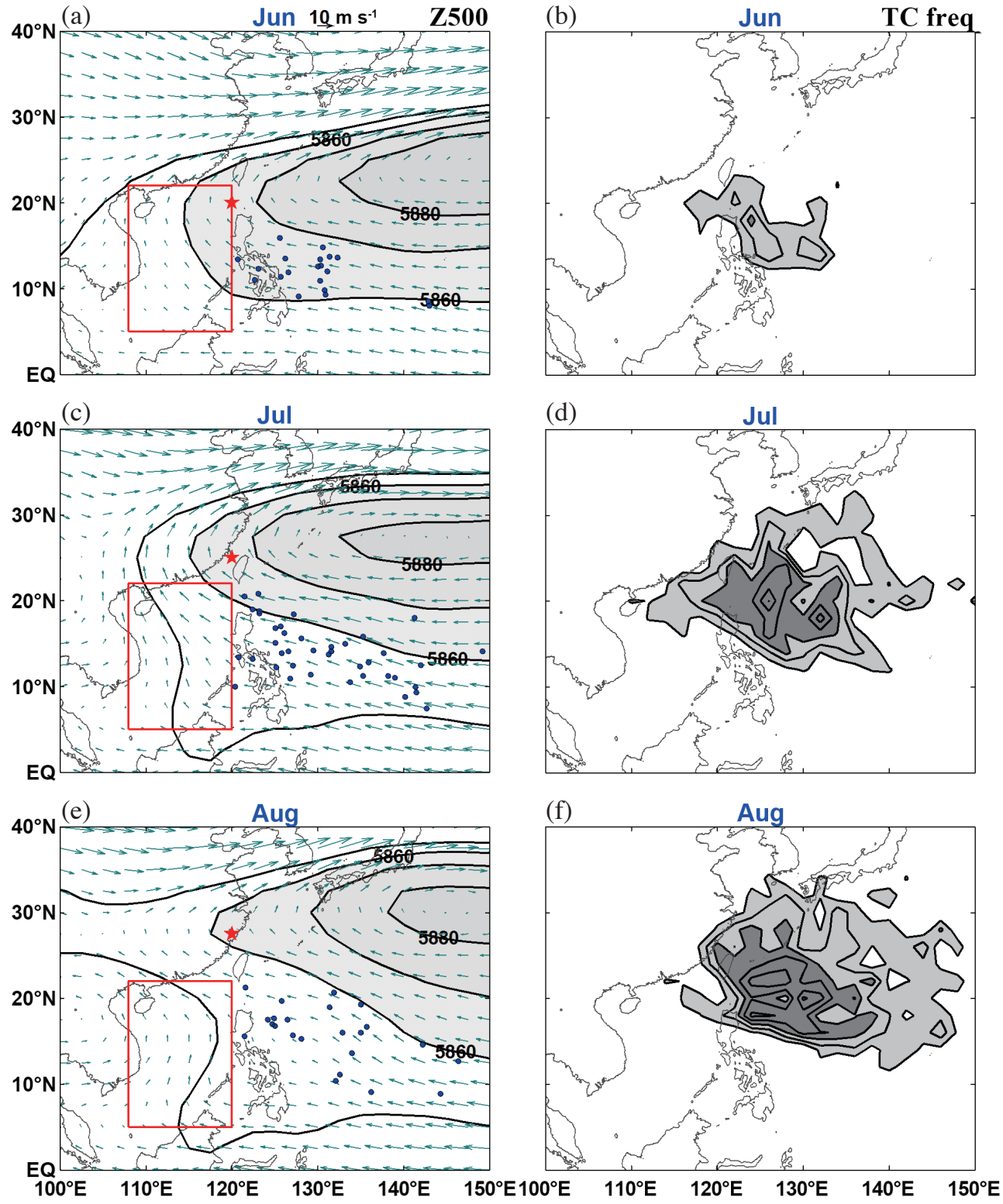

Fig. 7. The climatological means of 500-hPa height and wind fields superimposed with the formation locations of passage-type TCs (solid circle) for (a) June, (c) July, and (e) August. The asterisk mark denotes the axis position of the Pacific subtropical high along $120^{\circ} \mathrm{E}$. Also displayed are climatological means of TC frequency accumulated from a $2^{\circ} \times 2^{\circ}$ box for (b) June, (d) July, and (f) August. Contours of TC frequency are 0.1 . Values larger than $0.2(0.4)$ are lightly (heavily) shaded. (Color online only) 
northward shift during summer as found by the previous studies (e.g., Ueda and Yasunari 1996; Wu 2002). This shift is in accordance with the northward monsoon trough displacement. Passage-type TCs (denoted by a solid circle) tend to form to the south of the Pacific subtropical high axis, as revealed by the $5870-\mathrm{m}$ contour. TC frequency patterns disclose that the major WNP TC movements are in a more southern (northern) region during June (August). As indicated by areas with TC-frequency values larger than 0.4 , the major TC movements are in $14-26^{\circ} \mathrm{N}$ in July and $15-29^{\circ} \mathrm{N}$ in August. In June, the major domain is about $14-19^{\circ} \mathrm{N}$, as revealed by areas with contour values larger than 0.3 . In August, a more northwestward distribution of the Pacific subtropical high (Fig. 7e) facilitates WNP TCs in moving in a more northern region with evident northward movements (Fig. 7f), leading to a decreased chance of entering the SCS (only 12\%). On the other hand, the Pacific subtropical high is located more southward in June, resulting in an increased chance for the WNP TCs moving into the SCS (26\%).

Steering flow and TC frequency patterns for September to November are shown in Fig. 8. The salient feature of the steering flows appears as a westward-elongated Pacific subtropical high (Figs. 8a, c, e). This high extends further westward and moves southward during fall. As indicated by the western tip of the 5870-m contour, the westward extension enhances from $130^{\circ} \mathrm{E}$ in September to $122.5^{\circ} \mathrm{E}$ in November. For the southward migration, the Pacific subtropical high axis over $120^{\circ} \mathrm{E}$ (denoted by an asterisk) is
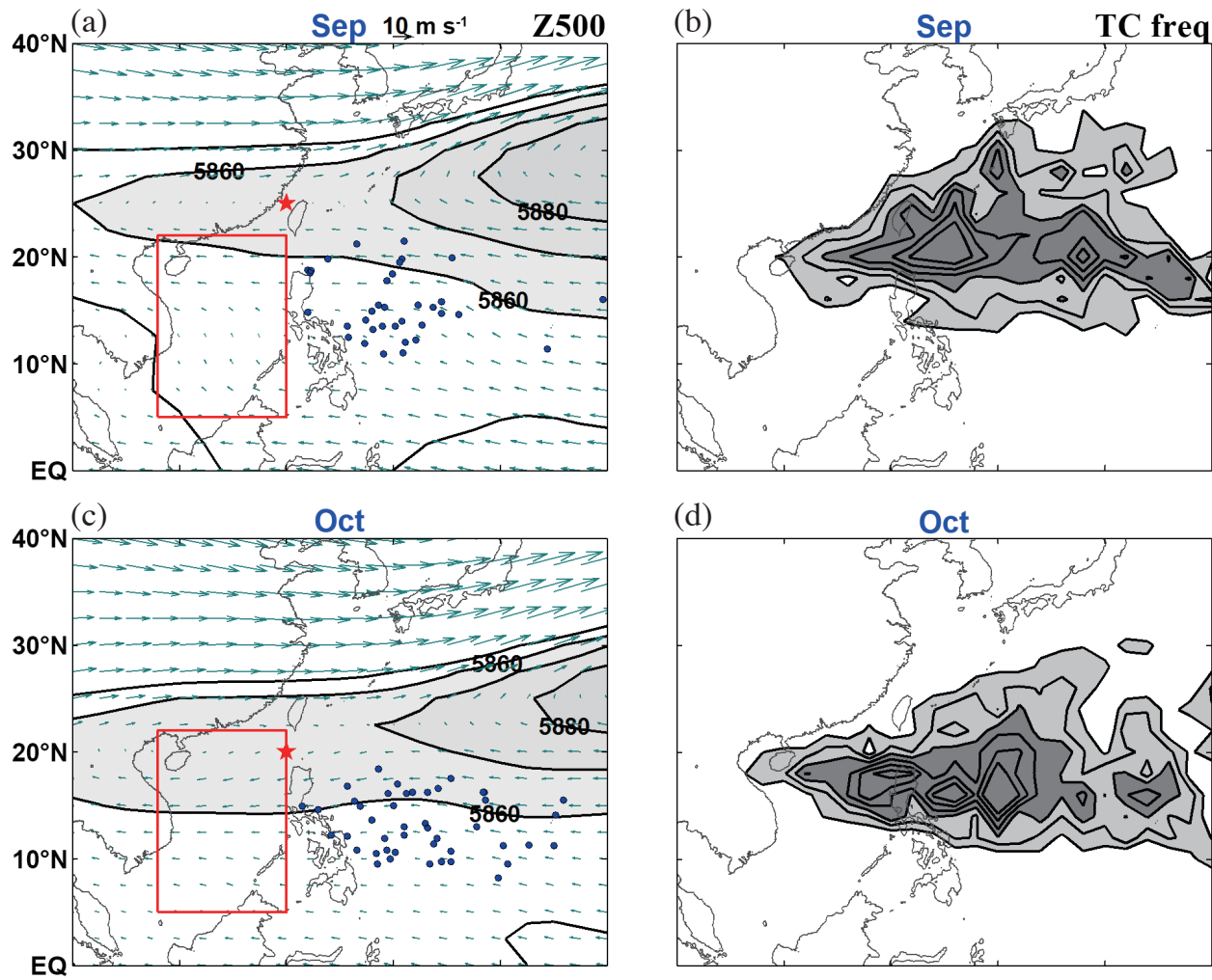

(d)
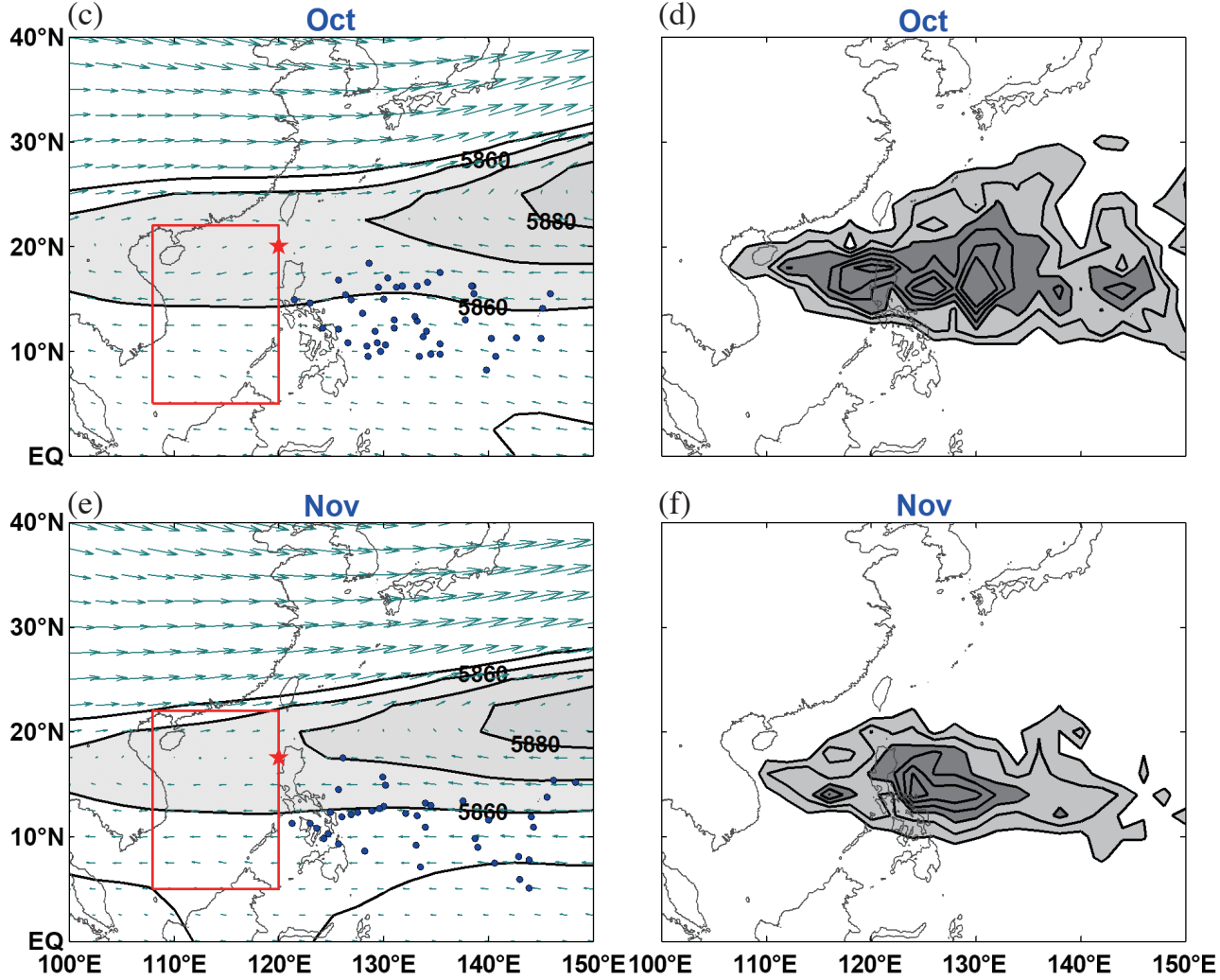

Fig. 8. As in Fig. 7, except for the climatological means of 500-hPa height and wind fields and TC frequency patterns for for (a)/(b) September, (c)/ (d) October, and (e)/(f) November. (Color online only) 
at about $25^{\circ} \mathrm{N}$ in September, $20^{\circ} \mathrm{N}$ in October, and $17.5^{\circ} \mathrm{N}$ in November. This displacement is coherent with the southward migration of TC formation locations (Figs. 8a, c, e) and the monsoon trough (Fig. 6). For TC movements, major TC frequency patterns (Figs. 8b, d, f) extend zonally from the WNP into the SCS. The major TC tracks moving into the SCS are mainly along latitude $20^{\circ} \mathrm{N}$ in September, $18^{\circ} \mathrm{N}$ in October, and $14^{\circ} \mathrm{N}$ in November. These major passage tracks displace southward during fall and are located to the south of the Pacific subtropical high axis. In addition to westward TC movements, there are also evident northward movements. Taking areas with contour values larger than 0.4 for analysis (dark shading), the meridional extensions of major TC movements are within $17-31^{\circ} \mathrm{N}$ in September, $12-24^{\circ} \mathrm{N}$ in October, and $12-18^{\circ} \mathrm{N}$ in November. A larger meridional extent toward the north in September than in November reflects more northward movements in the former month. The above analyses reveal that when the Pacific subtropical high displaces northward in September it corresponds with a more northern TC formation location, which in turn modulates TCs to move mainly farther northward on a more northern track. Harr and Elsberry (1991) found that TCs forming in a more northern region favor a northward recurving track. The northern SCS boundary is $22^{\circ} \mathrm{N}$. It is to the south of the Pacific subtropical high axis in September (about $25^{\circ} \mathrm{N}$ ). The WNP TCs moving in a region farther north apparently have less chance to enter the SCS. Thus, the major WNP TC tracks in the $17-31^{\circ} \mathrm{N}$ zone in September have less probability (18\%) of entering the SCS, when compared with the probability of November (32\%), a period associated with major tracks in the $12-18^{\circ} \mathrm{N}$ zone. The above analyses reveal that TC movements in a more northern (southern) region over the WNP reduce (enhance) the chances of entering the SCS during August and September (June and November). This feature can be clearly found in TC track patterns in August (Fig. 7f) and September (Fig. 8b). The probability of the WNP TCs entering the SCS thus decreases in these two months.

\section{LARGE-SCALE ENVIRONMENTS FAVORABLE FOR PASSAGE-TYPE TCS}

As shown in Fig. 4, the non-passage-type TCs may form in a position nearby passage-type TCs but undergo a different track. Harr and Elsberry (1991) found that TCs forming in the tropical WNP west of $150^{\circ} \mathrm{E}$ have a nearly equal chance of moving either northward or westward. TC tracks appear to be effectively influenced by large-scale steering induced by environmental background circulations (e.g., Wang et al. 1998; Harr and Elsberry 1995a, b). Thus, it is reasonable to speculate that some large-scale circulation feature(s) may concur with the formation of passagetype TCs and provide favorable conditions for TCs to move westward toward the SCS. To investigate this speculation, the large-scale environmental feature is interpreted from 10-day low-pass filtered circulation anomaly extracted by a fourth-order Butterworth bandpass filter scheme (e.g., Murakami 1979) using daily data from June to November in each year. The 10-day low-pass filtered components include the influences of major intraseasonal oscillations of $30-60$ and 10 - 24 days (e.g., Hartmann et al. 1992; Chen and Chen 1995; Chen et al. 2000; Ding 2007), which can exert evident influences on TC formation in the WNP (e.g., Li et al. 2012, 2014). The circulation feature associated with a TC itself is excluded from this component because TCs are normally considered as synoptic features with a life cycle less than 10 days.

The composite anomalies of 10-day low-pass filtered $500-\mathrm{hPa}$ winds from the formation days of all passage-type TCs are used to depict favorable environmental circulations associated with their formation. As shown in Fig. 9, passage-type TCs (denoted by a solid circle) tend to form in the eastern part of a zonally-elongated cyclonic circulation anomaly across the SCS and the tropical western Pacific in the $10-20^{\circ} \mathrm{N}$ zone. Throughout the major TC season, this cyclonic anomaly exhibits a center around the coasts of the Philippines or in the SCS (denoted by an asterisk). The cyclonic anomaly is paired with an anticyclonic anomaly to the north. Sandwiched by this meridional pair of cyclonic-anticyclonic anomalies, anomalous easterly flows extend westward from the subtropical WNP into the northern SCS. TCs are formed to the south of the anomalous easterly flows. To trace the subsequent circulation features accompanying TC movements toward the SCS, the composite anomalies of 10-day low-pass filtered $500-\mathrm{hPa}$ winds from the days when passage-type TCs enter the SCS (i.e., across the $120^{\circ} \mathrm{E}$ longitude) are shown in Fig. 10. The salient features from June to November turn out to be similar. A cyclonic anomaly centering at about $120^{\circ} \mathrm{E}$ is paired with an anticyclonic anomaly to the northeast. Anomalous easterly flows dominate from the subtropical WNP into the northern SCS. By comparing Figs. 9 and 10, one can find that favorable environmental circulations during the period from the formation of passage-type TCs in the WNP to their entrances into the SCS appear as a cyclonic anomaly on the southern side within the $10-20^{\circ} \mathrm{N}$ zone and an anticyclonic anomaly on the northern side within the $20-40^{\circ} \mathrm{N}$ zone. The anticyclonic anomaly has a center to the north of the cyclonic anomaly in June, September, and October, to the northeast in July and August, and to the northwest in November. The cyclonic anomaly is elongated across the SCS and the WNP during the formation stage and becomes more circular with a center over the SCS and the Philippines during the entrance day, showing a westward displacement in circulation patterns.

How do the anomalous circulation patterns shown in Fig. 9 facilitate the WNP TCs on a westward track into the SCS? The cyclonic anomaly in the $10-20^{\circ} \mathrm{N}$ zone stretches 
zonally more than $25^{\circ}$ in longitude. This spatial pattern resembles the so-called monsoon gyre (e.g., Lander 1994b), which can persist for 2 - 3 weeks as a long-lasting environment that modulates TC activity. Moreover, previous studies also showed that TCs tend to form in a cyclonic anomaly associated with the enhanced convective phases of 10- 24day and 30- 60-day modes, reflecting an effective modulation of intraseasonal oscillation on TC formation (e.g., Hall et al. 2001; Kim et al. 2008; Li et al. 2012; Li and Zhou 2013). The anomalous easterly flows sandwiched by the cyclonic-anticyclonic circulation anomalies enhance the cyclonic shear to the south, which acts as a favorable condition for a TC formed within the cyclonic anomaly to have a westward track (e.g., Harr and Elsberry 1995a). Meanwhile, the anticyclonic circulation to the north provides a steering effect that guides TCs on their southern side to move westward along with anomalous easterly flows (e.g., Choi et al. 2010). Further analyses of the composite low-pass filtered anomalies during the formation days disclose that the cyclonic anomaly is in company with anomalous positive vorticity and upward motions (not shown). After formation in the eastern part of the elongated cyclonic anomaly, TCs favor moving along the cyclonic anomaly for growth in an environment of positive vorticity and upward motion anomalies. This formation and growth pattern gives TCs a westward track from the WNP into the SCS.
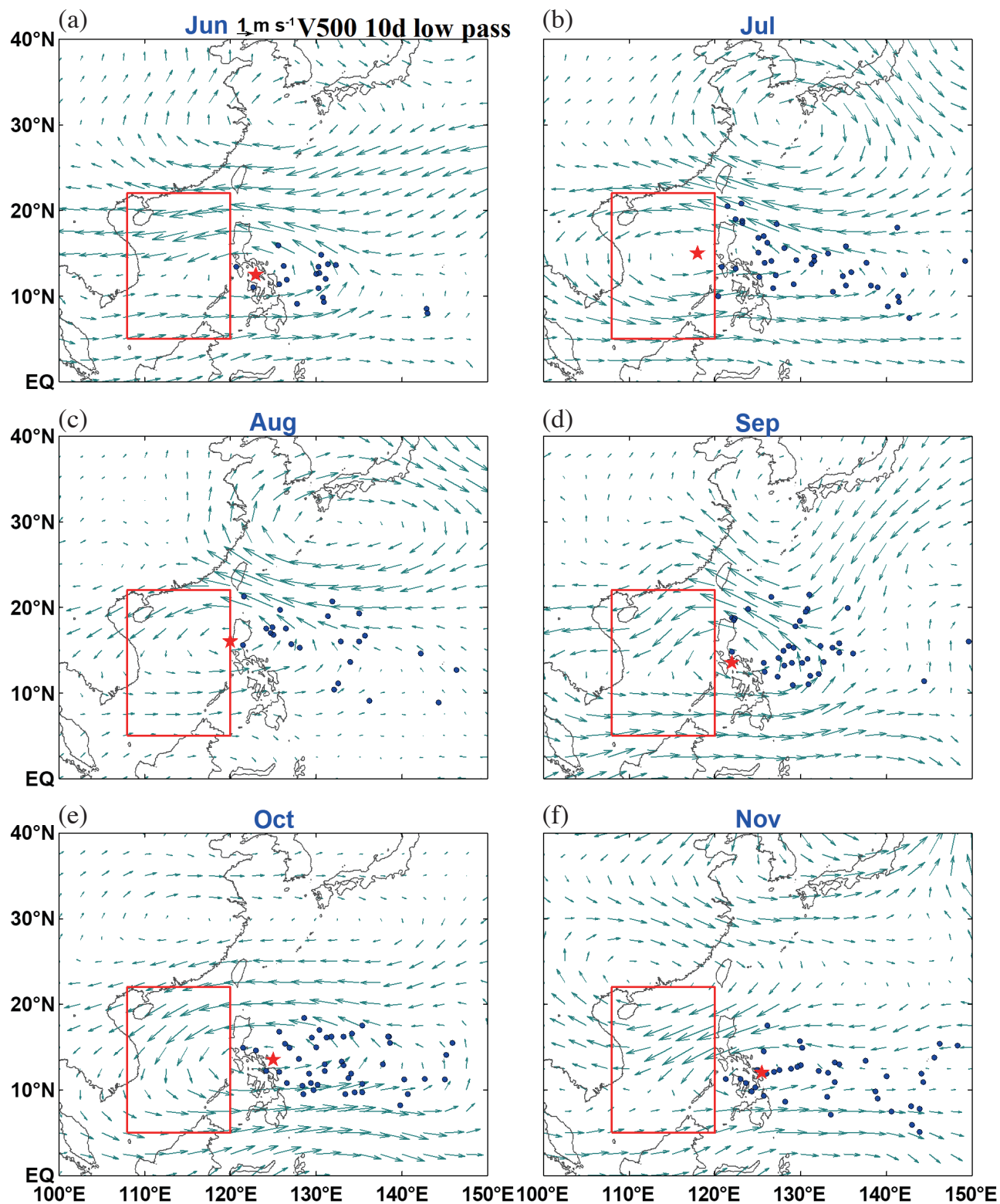

Fig. 9. The composite anomalies of 10-day low-pass filtered 500-hPa winds averaged from the formation days of all passage-type TCs for (a) June, (b) July, (c) August, (d) September, (e) October, and (f) November. The formation locations of passage-type TCs are marked with the solid circles. The asterisk denotes the center of the cyclonic anomaly across the SCS and the WNP. (Color online only) 

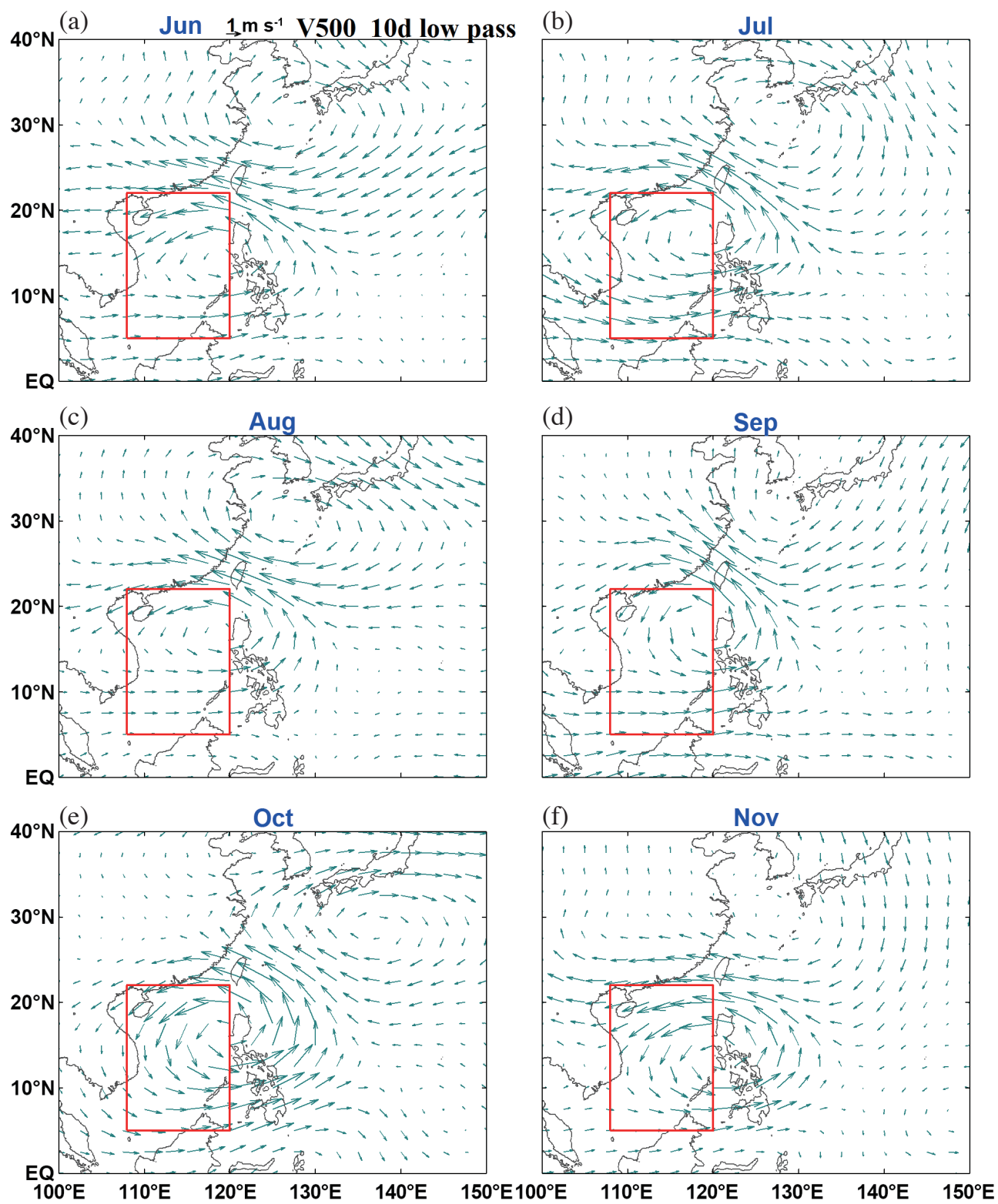

Fig. 10. As in Fig. 9, except for the composite anomalies of 10-day low-pass filtered 500-hPa winds averaged from the days when passage-type TCs enter the SCS. (Color online only)

\section{VARIATIONS IN MONSOON TROUGH AND PACIFIC SUBTROPICAL HIGH}

Large-scale circulation features affecting the passagetype TCs are depicted from two aspects: anomalous flows and total flows. The anomalous flows are investigated from the 10-day low-pass filtered anomalies discussed above, while the total flows with a close connection to formation and track of TCs have been found to be the monsoon trough and Pacific subtropical high (e.g., Elsberry 1987; Harr and Elsberry 1991). Analysis of the anomalous flows illustrates the controlling seasonal background flow effect on TC movements. Total flow analysis may be further applied to the development of a useful real-time index for monitoring or predicting the occurrence of a passage-type TC. To specifically demonstrate the modulating effects of the monsoon trough on the passage-type TCs, composite daily $850-\mathrm{hPa}$ height contours $(1490,1495$, and $1500 \mathrm{~m}$ ) averaged from the formation days for all passage-type TCs are compared with climatology. Similarly, composite daily 500-hPa height contours (5860 and $5865 \mathrm{~m}$ ) are used to illustrate variations in the Pacific subtropical high. As shown in Fig. 11, the formation of passage-type TCs in June and July is associated with a significantly southeastward expansion/deepening of the monsoon trough. This trough deepening is in company with a northward displacement of the Pacific subtropical high. In August, the monsoon trough exhibits a noticeable southward displacement, while a westward intensification occurs for 
the Pacific subtropical high. Figure 11 shows the variations in large-scale circulation features associated with passagetype TC formation during fall. In September, the monsoon trough exhibits a southward shift. Meanwhile, the Pacific subtropical high shows a clear westward intensification. In October and November, the monsoon trough intensifies with a noticeable meridional expansion/deepening, while the Pacific subtropical high features a northward displacement.

The monsoon trough and Pacific subtropical high associated with the formation of passage-type TCs reveal two types of systematic variations in the above analyses. When the Pacific subtropical high intensifies with a westward expansion, the monsoon trough to the south tends to vary with a southward displacement, as seen in August and September. When the monsoon trough intensifies with a southeastward (meridional) expansion in June - July (October - November), the Pacific subtropical high to the north displaces northward. It appears that the formation of passage-type TCs is concurrent with an intensification in one circulation feature and a displacement of the other circulation feature when in retreat (i.e., farther southward for the tropical monsoon trough and farther northward for the Pacific subtropical high). In August and September, TCs tend to form in a more northern region (see Fig. 5). Their climatological tracks show a majority of northward movements toward the northern/northwestern Pacific (see Figs. 7f and 8b), leading
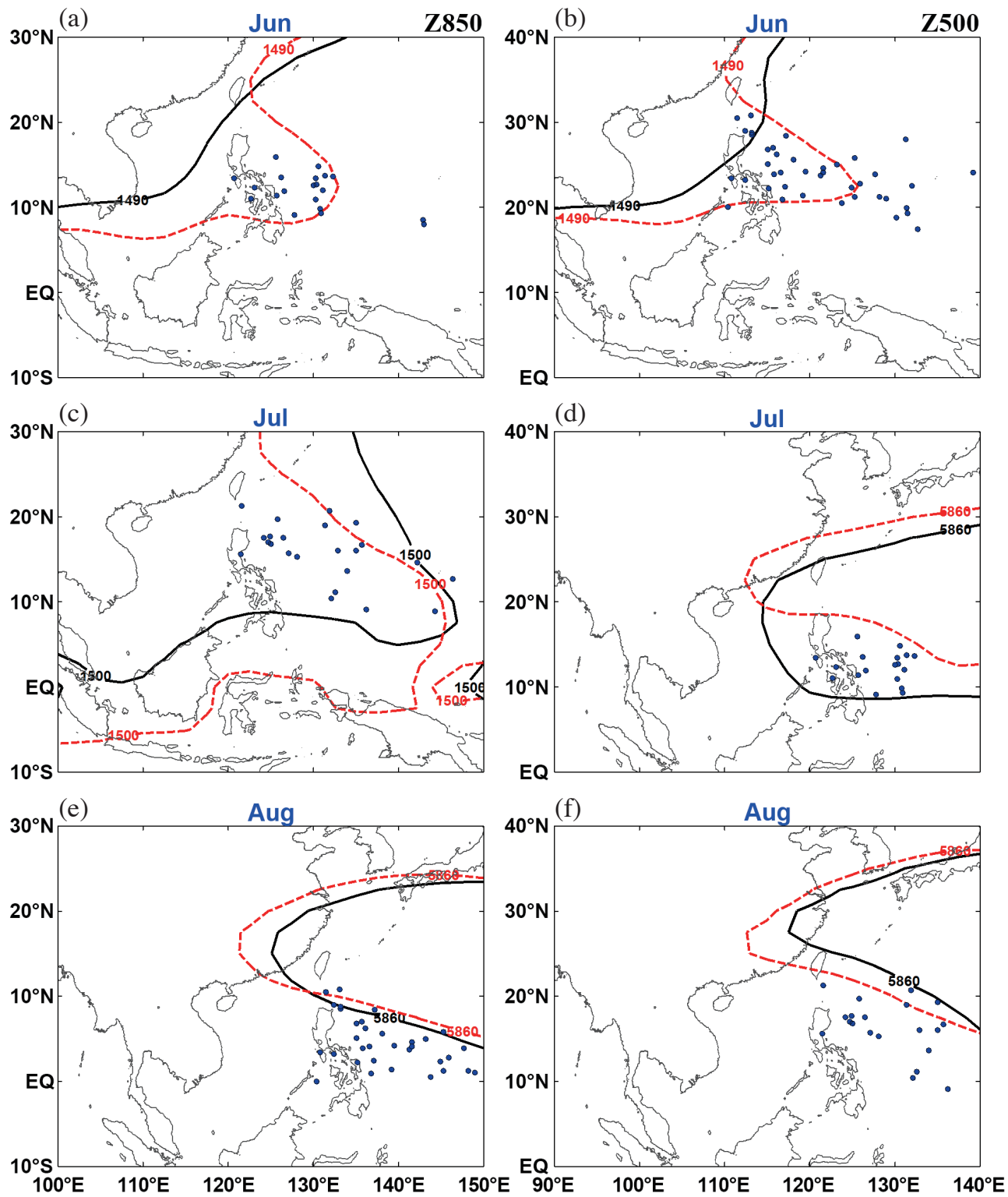

Fig. 11. The composite contours of $850-\mathrm{hPa}$ (a) (c) (e) and 500-hPa (b) (d) (f) height averaged from the formation days of all passage-type TCs formed in the WNP for the summer months (dashed lines). These contours are compared with the climatological positions (solid lines). The 850- and $500-\mathrm{hPa}$ contours are used to depict variations of the monsoon trough and Pacific subtropical high, respectively, associated with the formation of passage-type TCs. (Color online only) 
to decreased probability of the WNP TCs moving westward into the SCS (see Fig. 3b). Under the climatologically unfavorable conditions for passage-type TCs, the westward/ southward intensifications of the Pacific subtropical high during TC formation days can force TCs to form in a more southern region. Meanwhile, the intensified subtropical high can hinder TCs' northward movements, providing a favorable condition for their westward movements to become the passage-type TCs.

In June - July, TC-formation locations tend to be in a more southern region. The southeastward expansion of the monsoon trough stretches from the SCS into the tropical WNP. The monsoon trough presence is accompanied by strong positive vorticity and thus helps TC development within the trough (Wang et al. 2007). The southeastward expansion provides favorable environments for attracting TCs formed in the southeastern part of the trough toward the core trough region and thus toward the SCS (Figs. 11a and c). Lander (1996) demonstrated that when the monsoon trough axis is in a northwest-southeast (southwest-northeast) orientation, the WNP TCs tend to move with a westward (northward) track. The southeastward monsoon trough expansion in June - July acts as a favorable factor to guide the WNP TCs westward into the SCS.

In October - November, the monsoon trough axis is located in a very low latitude, $11.5^{\circ} \mathrm{N}$ in October and $7.5^{\circ} \mathrm{N}$ in November (see Figs. 6e - f), in company with a more southern location for TC formation. In these two months, the meridional monsoon trough expansion extends westward into the SCS (see Figs. 12c and e) and thus provides favorable environments over the SCS for TCs to move in and develop. The expanded monsoon trough in October also exhibits a northwest-southeast orientation to facilitate westward TC movement. The northward-displaced Pacific subtropical high still has its southern periphery across the SCS, where easterly flows are effective in guiding the WNP TCs westward toward the SCS.

\section{CONCLUDING REMARKS}

The SCS is a tropical marginal sea adjacent to the WNP. Both the SCS and the WNP are known for vigorous TC activity. TCs formed in the WNP generally exhibit three major movement tracks: northward toward the northern North Pacific, northwestward toward the northwestern North Pacific/East Asia, and westward toward the SCS/ southern China. As such, TCs appearing in the SCS come from two major sources: in situ formation and passage from the WNP. The climatological characteristics of TCs that pass from the WNP into the SCS were analyzed in this study using 1950 - 2010 data. The TCs analyzed present tropical storm intensity or greater. The TC time and location with maximum sustained wind speed greater than or equal to 34 knots were used to characterize TC commencement.
Our analyses show that TC activity in the SCS is significant from June to November (major TC season). A TC originally forming in the WNP with (without) a subsequent movement into the SCS is categorized as a passage-type (non-passage-type) TC. The relative importance of passagetype TCs to total TC activity in the SCS shows clear seasonality. They contribute $51-57 \%$ of total TCs appearing in the SCS $\left(108-120^{\circ} \mathrm{E}, 5-22^{\circ} \mathrm{N}\right)$ during June - July, deceasing to only $35-41 \%$ during August - September, and back to 60 - $61 \%$ during October - November. The above seasonality varies coherently with the probability of a WNP TC moving into the SCS. The relative percentages of passage-type TCs to total TCs formed in the WNP $\left(120-180^{\circ} \mathrm{E}, 5-22^{\circ} \mathrm{N}\right)$ are 25 - 26\% during June - July, decreasing to 12 - $18 \%$ during August - September, and up to 25 - $32 \%$ during October November.

The passage-type TCs exhibit noticeable formation features. They prefer to form in regions west of $150^{\circ} \mathrm{E}$, $100 \%$ during summer and $92-93 \%$ during fall. On average, passage-type TCs tend to form in a more western region than non-passage-type TCs, about $7.28-10.83^{\circ}$ westward during summer and $11.23-12.37^{\circ}$ during fall. The average formation locations exhibit clear seasonality, moving northward from June to August but southward from September to November. Migrations of formation locations are found to be coherent with meridional movements of the monsoon trough. TC formation and the Pacific subtropical high coherently displace to a more northern (southern) region in August and September (June and November). The northward displacement of the Pacific subtropical high allows TCs to move in a more northern region, which in turn favors a northward recurving track. As such, the probability for these WNP TCs undergoing a westward track toward the tropical SCS decreases in August and September. In June and November, both TC formation and the Pacific subtropical high shift southward. TCs tend to move westward along with the easterly flows on the southern periphery of the $\mathrm{Pa}$ cific subtropical high, leading to increasing probability of moving westward toward the tropical SCS.

Large-scale environmental circulations favorable for passage-type TCs exhibit evident common features during the period from formation day in the WNP to entrance day into the SCS. As revealed by the composite anomalies for 10-day low-pass filtered circulation, the passage-type TCs tend to form in the eastern part of a lower-level cyclonic anomaly located in the $10-20^{\circ} \mathrm{N}$ zone. This anomaly extends zonally across the SCS and the tropical WNP, with a center near the coasts of the Philippines. It is paired with an anticyclonic anomaly to the north. TCs formed in the eastern part of the cyclonic circulation anomaly are guided by anomalous easterly flows on the southern periphery of the anticyclonic anomaly to favor a westward track. Moreover, the cyclonic anomaly is accompanied by positive vorticity and upward motion anomalies, which attract TCs to move 
in that direction as they develop. As such, TCs embedded in this cyclonic-anticyclonic pair follow favorable conditions to cyclone development as they move westward toward the SCS.

The monsoon trough and Pacific subtropical high exhibit coherent systematic variation features in association with the formation of passage-type TCs. In August and September, the variations appear as a southward displacement of the monsoon trough and a westward intensification of the Pacific subtropical high. The Pacific subtropical high intensification also expands southward, which tends to guide TCs into a westward track in a more southern region via anomalous easterly flows on its southern periphery. This provides favorable conditions for the WNP TCs to move westward toward the SCS. During June - July (October - November), the associated features appear as a southeastward (meridional) expansion of the monsoon trough and a northward displacement of the Pacific subtropical high. In these months, TCs are formed in a more southern region. The deepening and expansion of the monsoon trough provide more favorable conditions over the SCS and the tropical WNP for the WNP TCs to move in and develop. They thus attract TCs to undergo a westward track from the WNP into the SCS.

Analyses in this study show that the formation and movements of passgae-type TCs are influenced by the seasonal environmental circulation anomalies. This frequency mode includes the 10- 24-day and 30- 60-day modes, which are the major components of intraseasonal oscillations
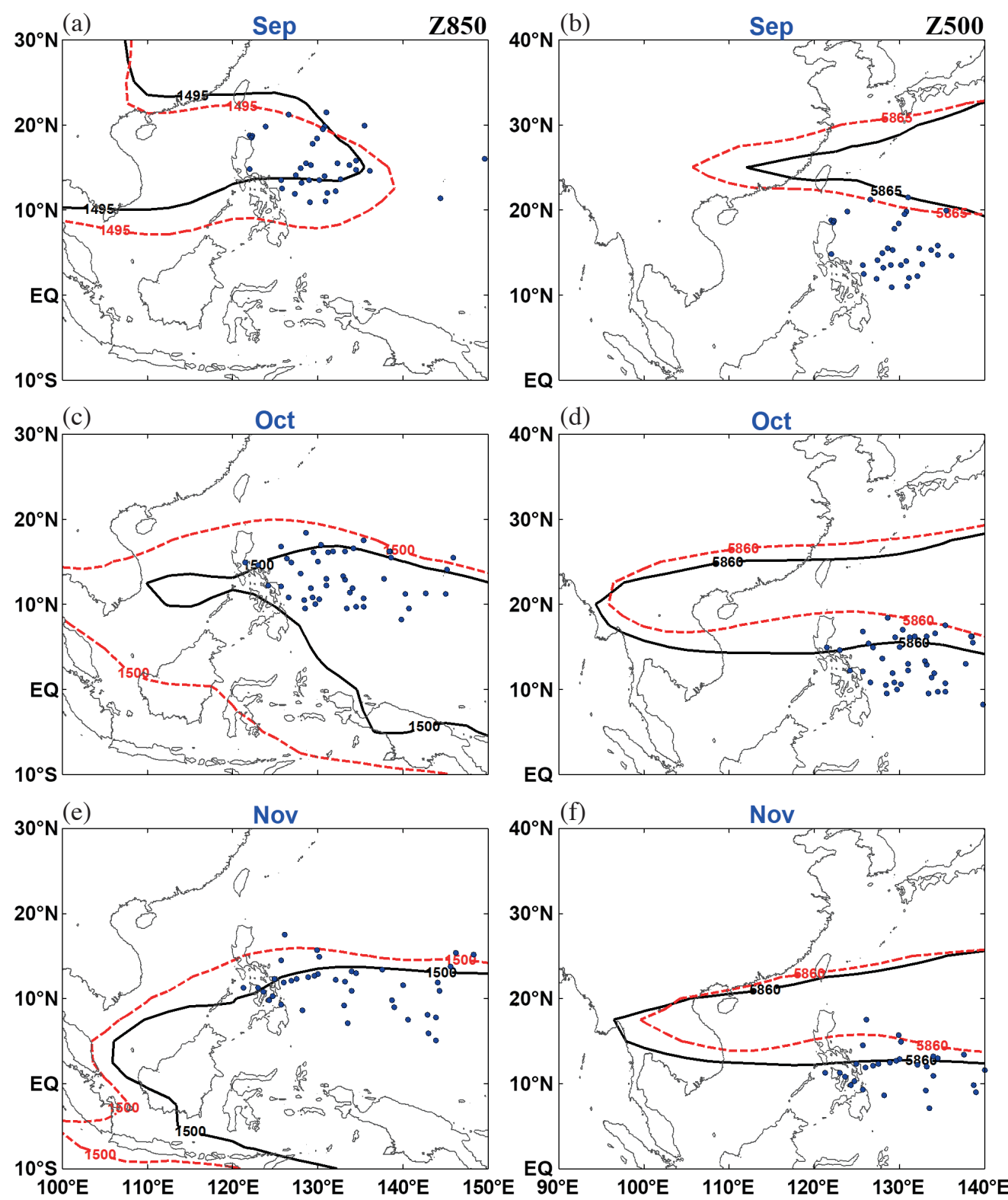

Fig. 12. As in Fig. 11, except for variations in the monsoon trough and Pacific subtropical high associated with the formation of passage-type TCs for the fall months. (Color online only) 
in the Asian-Pacific regions (e.g., Chen and Chen 1995; Ding 2007). Both the monsoon trough and Pacific subtropical high show systematic variability features in association with the formation of passage-type TCs. These two circulation features also exhibit noticeable intraseasonal variability (e.g., Chen et al. 2009; Ko and Hsu 2009). Thus, it is expected that intraseasonal oscillations should exert certain effects on the characteristics of passgae-type TCs. For example, how do the propagation features of 10- 24-day and 30 - 60-day modes affect the formation and movements of passgae-type TCs? The influences of intraseonal oscillations on passage-type TCs have not been examined. These related issues are worthy of further study.

Acknowledgements The authors would like to thank the anonymous reviewers for their valuable comments which improved this paper. This study was supported by the Ministry of Science and Technology, Taiwan, under MOST 103-2111-M022-002-MY3 and MOST 104-2111-M-022-001. Liang Wu was supported by the National Natural Science Foundation of China Grants 41461164005 and 41475077.

\section{REFERENCES}

Camargo, S. J. and A. H. Sobel, 2005: Western North Pacific tropical cyclone intensity and ENSO. J. Climate, 18, 2996-3006, doi: 10.1175/JCLI3457.1. [Link]

Camargo, S. J., A. W. Robertson, S. J. Gaffney, P. Smyth, and M. Ghil, 2007: Cluster analysis of typhoon tracks. Part I: General properties. J. Climate, 20, 3635-3653, doi: 10.1175/JCLI4188.1. [Link]

Chen, G., 2011: How does shifting Pacific Ocean warming modulate on tropical cyclone frequency over the South China Sea? J. Climate, 24, 4695-4700, doi: 10.1175/2011JCLI4140.1. [Link]

Chen, J. M. and H. S. Chen, 2011: Interdecadal variability of summer rainfall in Taiwan associated with tropical cyclones and monsoon. J. Climate, 24, 5786-5798, doi: 10.1175/2011JCLI4043.1. [Link]

Chen, J. M., F. C. Lu, S. L. Kuo, and C. F. Shih, 2005: Summer climate variability in Taiwan and associated largescale processes. J. Meteorol. Soc. Jpn., 83, 499-516, doi: $10.2151 /$ jmsj.83.499. [Link]

Chen, J. M., H. S. Chen, and J. S. Liu, 2013: Coherent interdecadal variability of tropical cyclone rainfall and seasonal rainfall in Taiwan during October. J. Climate, 26, 308-321, doi: 10.1175/JCLI-D-11-00697.1. [Link]

Chen, T. C. and J. M. Chen, 1995: An observational study of the South China Sea monsoon during the 1979 summer: Onset and life cycle. Mon. Weather Rev., 123, 2295-2318, doi: 10.1175/1520-0493(1995)123<2295: AOSOTS $>2.0 . C O ; 2$. [Link]

Chen, T. C. and S. P. Weng, 1998: Interannual variation of the summer synoptic-scale disturbance activity in the western tropical Pacific. Mon. Weather Rev., 126, 1725-1733, doi: 10.1175/1520-0493(1998)126<1725:I VOTSS>2.0.CO;2. [Link]

Chen, T. C., M. C. Yen, and S. P. Weng, 2000: Interaction between the summer monsoons in East Asia and the South China Sea: Intraseasonal monsoon modes. J. Atmos. Sci., 57, 1373-1392, doi: 10.1175/1520-0469(200 0)057<1373:IBTSMI>2.0.CO;2. [Link]

Chen, T. C., S. Y. Wang, M. C. Yen, and W. A. Gallus Jr., 2004: Role of the monsoon gyre in the interannual variation of tropical cyclone formation over the western North Pacific. Weather Forecast., 19, 776-785, doi: 10.1175/1520-0434(2004)019<0776:ROTMGI >2 .0.CO;2. [Link]

Chen, T. C., S. Y. Wang, and M. C. Yen, 2006: Interannual variation of the tropical cyclone activity over the western North Pacific. J. Climate, 19, 5709-5720, doi: 10.1175/JCLI3934.1. [Link]

Chen, T. C., S. Y. Wang, M. C. Yen, and A. J. Clark, 2009: Impact of the intraseasonal variability of the western North Pacific large-scale circulation on tropical cyclone tracks. Weather Forecast., 24, 646-666, doi: 10.1175/2008WAF2222186.1. [Link]

Chia, H. H. and C. F. Ropelewski, 2002: The interannual variability in the genesis location of tropical cyclones in the northwest Pacific. J. Climate, 15, 2934-2944, d oi: 10.1175/1520-0442(2002)015<2934:TIVITG>2.0. $\mathrm{CO} ; 2$. [Link]

Choi, K. S., C. C. Wu, and E. J. Cha, 2010: Change of tropical cyclone activity by Pacific-Japan teleconnection pattern in the western North Pacific. J. Geophys. Res., 115, D19114, doi: 10.1029/2010JD013866. [Link]

Chu, J. H., C. R. Sampson, A. S. Levine, and E. Fukada, 2002: The Joint Typhoon Warning Center tropical cyclone best tracks, 1945-2000. Tech. Rep. NRL/ MR/7540-02-16, Naval Research Laboratory, Washington, DC. Available at http://www.usno.navy.mil/ NOOC/nmfc-ph/RSS/jtwc/best tracks/.

Chu, P. S., X. Zhao, C. H. Ho, H. S. Kim, M. M. Lu, and J. H. Kim, 2010: Bayesian forecasting of seasonal typhoon activity: A track-pattern-oriented categorization approach. J. Climate, 23, 6654-6668, doi: 10.1175/2010JCLI3710.1. [Link]

Colbert, A. J., B. J. Soden, and B. P. Kirtman, 2015: The impact of natural and anthropogenic climate change on western North Pacific tropical cyclone tracks. J. Climate, 28, 1806-1823, doi: 10.1175/JCLI-D-14-00100.1. [Link]

Ding, Y., 2007: The variability of the Asian summer monsoon. J. Meteorol. Soc. Jpn., 85B, 21-54, doi: 10.2151/ jmsj.85B .21. [Link]

Elsberry, R. L., 1987: Tropical cyclone motion. In: Elsberry, R. L. (Ed.), A Global View of Tropical Cyclones, US Office of Naval Research, Marine Meteorology 
Program, Washington, DC, USA, 91-131.

Elsner, J. B. and K. Liu, 2003: Examining the ENSO-typhoon hypothesis. Clim. Res., 25, 43-54, doi: 10.3354/ cr025043. [Link]

Haghroosta, T. and W. R. Ismail, 2013: Changes in sea surface temperature and precipitation rate during typhoons in the South China Sea. Int. J. Environ. Sci. Dev., 4, 390-392, doi: 10.7763/IJESD.2013.V4.378. [Link]

Hall, J. D., A. J. Matthews, and D. J. Karoly, 2001: The modulation of tropical cyclone activity in the Australian region by the Madden-Julian oscillation. Mon. Weather Rev., 129, 2970-2982, doi: 10.1175/1520-049 3(2001)129<2970:TMOTCA > 2.0.CO;2. [Link]

Harr, P. A. and R. L. Elsberry, 1991: Tropical cyclone track characteristics as a function of large-scale circulation anomalies. Mon. Weather Rev., 119, 1448-1468, doi: 10.1175/1520-0493(1991)119<1448:TCTCAA > 2.0.C $\mathrm{O} ; 2$. [Link]

Harr, P. A. and R. L. Elsberry, 1995a: Large-scale circulation variability over the tropical western North Pacific. Part I: Spatial patterns and tropical cyclone characteristics. Mon. Weather Rev., 123, 1225-1246, doi: 10.1 175/1520-0493(1995)123<1225:LSCVOT>2.0.CO;2 . [Link]

Harr, P. A. and R. L. Elsberry, 1995b: Large-scale circulation variability over the tropical western North Pacific. Part II: Persistence and transition characteristics. Mon. Weather Rev., 123, 1247-1268, doi: 10.1175/1520-049 3(1995) 123<1247:LSCVOT>2.0.CO;2. [Link]

Hartmann, D. L., M. L. Michelsen, and S. A. Klein, 1992: Seasonal variations of tropical intraseasonal oscillations: A 20-25-day oscillation in the western Pacific. $J$. Atmos. Sci., 49, 1277-1289, doi: 10.1175/1520-0469(1 992)049<1277:SVOTIO>2.0.CO;2. [Link]

Ho, C. H., J. J. Baik, J. H. Kim, D. Y. Gong, and C. H. Sui, 2004: Interdecadal changes in summertime typhoon tracks. J. Climate, 17, 1767-1776, doi: 10.1175/1520-0 442(2004)017<1767:ICISTT>2.0.CO;2. [Link]

Huang, P., C. Chou, and R. Huang, 2011: Seasonal modulation of tropical intraseasonal oscillations on tropical cyclone geneses in the western North Pacific. J. Climate, 24, 6339-6352, doi: 10.1175/2011JCLI4200.1. [Link]

Huang, Q. and Y. Guan, 2012: Does the Asian monsoon modulate tropical cyclone activity over the South China Sea? Chin. J. Oceanol. Limnol., 30, 960-965, doi: 10.1007/s00343-012-1273-x. [Link]

Kalnay, E., M. Kanamitsu, R. Kistler, W. Collins, D. Deaven, L. Gandin, M. Iredell, S. Saha, G. White, J. Woollen, Y. Zhu, A. Leetmaa, R. Reynolds, M. Chelliah, W. Ebisuzaki, W. Higgins, J. Janowiak, K. C. Mo, C. Ropelewski, J. Wang, R. Jenne, and D. Joseph, 1996: The NCEP/NCAR 40-year Reanalysis Project. Bull. Amer. Meteorol. Soc., 77, 437-471, doi: 10.1175/1520
-0477(1996)077<0437:TNYRP>2.0.CO;2. [Link]

Kim, H. M., M. I. Lee, P. J. Webster, D. Kim, and J. H. Yoo, 2013: A physical basis for the probabilistic prediction of the accumulated tropical cyclone kinetic energy in the western North Pacific. J. Climate, 26, 7981-7991, doi: 10.1175/JCLI-D-12-00679.1. [Link]

Kim, H. S., C. H. Ho, J. H. Kim, and P. S. Chu, 2012: Track-pattern-based model for seasonal prediction of tropical cyclone activity in the western North Pacific. J. Climate, 25, 4660-4678, doi: 10.1175/JCLID-11-00236.1. [Link]

Kim, J. H., C. H. Ho, H. S. Kim, C. H. Sui, and S. K. Park, 2008: Systematic variation of summertime tropical cyclone activity in the Western North Pacific in relation to the Madden-Julian Oscillation. J. Climate, 21, 11711191, doi: 10.1175/2007JCLI1493.1. [Link]

Ko, K. C. and H. H. Hsu, 2006: Sub-monthly circulation features associated with tropical cyclone tracks over the East Asian monsoon area during July-August season. J. Meteorol. Soc. Jpn., 84, 871-889, doi: 10.2151/ jmsj.84.871. [Link]

Ko, K. C. and H. H. Hsu, 2009: ISO modulation on the submonthly wave pattern and recurving tropical cyclones in the tropical western North Pacific. J. Climate, 22, 582-599, doi: 10.1175/2008JCLI2282.1. [Link]

Lander, M. A., 1994a: An exploratory analysis of the relationship between tropical storm formation in the western North Pacific and ENSO. Mon. Weather Rev., 122, 636-651,doi: 10.1175/1520-0493(1994)122<0636:AEAOTR $>2.0 . C O ; 2$. [Link]

Lander, M. A., 1994b: Description of a monsoon gyre and its effects on the tropical cyclones in the western North Pacific during August 1991. Weather Forecast., 9, 640-654, doi: 10.1175/1520-0434(1994)009<0640:D OAMGA>2.0.CO;2. [Link]

Lander, M. A., 1996: Specific tropical cyclone track types and unusual tropical cyclone motions associated with a reverse-oriented monsoon trough in the western North Pacific. Weather Forecast., 11, 170-186, doi: 10.117 5/1520-0434(1996)011<0170:STCTTA>2.0.CO;2. [Link]

Lee, C. S., Y. L. Lin, and K. K. W. Cheung, 2006: Tropical cyclone formations in the South China Sea associated with the Mei-Yu front. Mon. Weather Rev., 134, 26702687, doi: 10.1175/MWR3221.1. [Link]

Li, R. C. Y. and W. Zhou, 2013: Modulation of western North Pacific tropical cyclone activity by the ISO. Part I: Genesis and intensity. J. Climate, 26, 2904-2918, doi: 10.1175/JCLI-D-12-00210.1. [Link]

Li, R. C. Y. and W. Zhou, 2015: Interdecadal changes in summertime tropical cyclone precipitation over Southeast China during 1960-2009. J. Climate, 28, 14941509, doi: 10.1175/JCLI-D-14-00246.1. [Link]

Li, R. C. Y., W. Zhou, J. C. L. Chan, and P. Huang, 2012: 
Asymmetric modulation of western North Pacific cyclogenesis by the Madden-Julian oscillation under ENSO conditions. J. Climate, 25, 5374-5385, doi: 10.1175/JCLI-D-11-00337.1. [Link]

Li, R. C. Y., W. Zhou, and T. Li, 2014: Influences of the Pacific-Japan teleconnection pattern on synoptic-scale variability in the western North Pacific. J. Climate, 27, 140-154, doi: 10.1175/JCLI-D-13-00183.1. [Link]

Li, R. C. Y., W. Zhou, and T. C. Lee, 2015: Climatological characteristics and observed trends of tropical cycloneinduced rainfall and their influences on long-term rainfall variations in Hong Kong. Mon. Weather Rev., 143, 2192-2206, doi: 10.1175/MWR-D-14-00332.1. [Link]

Lin, Y. L. and C. S. Lee, 2011: An analysis of tropical cyclone formations in the South China Sea during the late season. Mon. Weather Rev., 139, 2748-2760, doi: 10.1175/2011MWR3495.1. [Link]

Ling, Z., G. Wang, C. Wang, and Z. S. Fan, 2011: Different effects of tropical cyclones generated in the South China Sea and the northwest Pacific on the summer South China Sea circulation. J. Oceanogr., 67, 347-355, doi: 10.1007/s10872-011-0044-1. [Link]

McBride, J. J., 1995: Tropical cyclone formation: Global perspectives on tropical cyclones. WMO/TD-No. 693, World Meteorological Organization, 63-105.

Mei, W., S. P. Xie, M. Zhao, and Y. Wang, 2015: Forced and internal variability of tropical cyclone track density in the western North Pacific. J. Climate, 28, 143167, doi: 10.1175/JCLI-D-14-00164.1. [Link]

Murakami, M., 1979: Large-scale aspects of deep convective activity over the GATE area. Mon. Weather Rev., 107, 994-1013, doi: 10.1175/1520-0493(1979)107<09 94:LSAODC>2.0.CO;2. [Link]

Neumann, C., 1993: Global overview. In: Holland, G. J. (Ed.), The Global Guide to Tropical Cyclone Forecasting, WTO/TD-560, World Meteorological Organization, Geneva, 3.1-3.46.

Ritchie, E. A. and G. J. Holland, 1999: Large-scale patterns associated with tropical cyclogenesis in the western Pacific. Mon. Weather Rev., 127, 2027-2043, doi: 10 .1175/1520-0493(1999)127<2027:LSPAWT>2.0.CO; 2. [Link]

Takahashi, H. G. and T. Yasunari, 2008: Decreasing trend in rainfall over Indochina during the late summer monsoon: Impact of tropical cyclones. J. Meteorol. Soc. Jpn., 86, 429-438, doi: 10.2151/jmsj.86.429. [Link]

Tippett, M. K., S. J. Camargo, and A. H. Sobel, 2011: A Poisson regression index for tropical cyclone genesis and the role of large-scale vorticity in genesis. J. Climate, 24, 2335-2357, doi: 10.1175/2010JCLI3811.1. [Link]

Ueda, H. and T. Yasunari, 1996: Maturing process of the summer monsoon over the Western North Pacific: A coupled ocean/atmosphere system. J. Meteorol. Soc. Jpn., 74, 493-508, doi: 10.2151/jmsj1965.74.4_493. [Link]

Wang, B. and J.C. L. Chan, 2002: How strong ENSO events affect tropical storm activity over the Western North Pacific. J. Climate, 15, 1643-1658, doi: 10.1175/15200442(2002)015<1643:HSEEAT>2.0.CO;2. [Link]

Wang, B., R. L. Elsberry, Y. Wang, and L. Wu, 1998: Dynamics in the tropical storm activity over the western North Pacific. Chinese J. Atmos. Sci., 22, 535-547.

Wang, G., J. Su, Y. Ding, and D. Chen, 2007: Tropical cyclone genesis over the south China sea.J.Mar. Syst., 68, 318-326, doi: 10.1016/j.jmarsys.2006.12.002. [Link]

Wang, X., W. Zhou, C. Li, and D. Wang, 2012: Effects of the East Asian summer monsoon on tropical cyclone genesis over the South China Sea on an interdecadal time scale. Adv. Atmos. Sci., 29, 249-262, doi: 10.1007/ s00376-011-1080-x. [Link]

Wang, X., W.Zhou, C. Li, and D. Wang, 2014: Comparison of the impact of two types of El Niño on tropical cyclone genesis over the South China Sea. Int. J. Climatol., 34, 2651-2660, doi: 10.1002/joc.3865. [Link]

Wu, L. and B. Wang, 2000: A potential vorticity tendency diagnostic approach for tropical cyclone motion. Mon. Weather Rev., 128, 1899-1911, doi: 10.1175/1520-049 3(2000)128<1899:APVTDA>2.0.CO;2. [Link]

Wu, L. and B. Wang, 2004: Assessing impacts of global warming on tropical cyclone tracks. J. Climate, 17, 1686-1698, doi: 10.1175/1520-0442(2004)017<1686: AIOGWO $>2.0 . C O ; 2$. [Link]

$\mathrm{Wu}, \mathrm{R} ., 2002$; Processes for the northeastward advance of the summer monsoon over the western North Pacific. J. Meteorol. Soc. Jpn., 80, 67-83, doi: 10.2151/ jmsj.80.67. [Link]

Yan, Y., Y. Qi, and W. Zhou, 2012: Variability of tropical cyclone occurrence date in the South China Sea and its relationship with SST warming. Dyn. Atmos. Oceans, 55-56, 45-59, doi: 10.1016/j.dynatmoce.2012.05.001. [Link]

Yoshida, R. and H. Ishikawa, 2013: Environmental factors contributing to tropical cyclone genesis over the western North Pacific. Mon. Weather Rev., 141, 451-467, doi: 10.1175/MWR-D-11-00309.1. [Link]

Zhao, H., L. Wu, and W. Zhou, 2011: Interannual changes of tropical cyclone intensity in the western North Pacific. J. Meteorol. Soc. Jpn., 89, 243-253, doi: 10.2151/ jmsj.2011-305. [Link]

Zhao, H., P. S. Chu, P. C. Hsu, and H. Murakami, 2014: Exploratory analysis of extremely low tropical cyclone activity during the late-season of 2010 and 1998 over the western North Pacific and the South China Sea. J. Adv. Model. Earth Syst., 6, 1141-1153, doi: 10.1002/2014MS000381. [Link] 